\title{
Blast Vulnerability of Multi-Storey Masonry Infill Reinforced Concrete Frames
}

\author{
Saba Shamim*, Shakeel Ahmad, Rehan Ahmad Khan \\ Department of Civil Engineering, Aligarh Muslim University (A.M.U.), Aligarh, India
}

Received August 4, 2020; Revised April 2, 2021; Accepted May 23, 2021

\section{Cite This Paper in the following Citation Styles}

(a): [1] Saba Shamim, Shakeel Ahmad, Rehan Ahmad Khan, "Blast Vulnerability of Multi-Storey Masonry Infill Reinforced Concrete Frames," Civil Engineering and Architecture, Vol. 9, No. 3, pp. 853 - 868, 2021. DOI: 10.13189/cea.2021.090327.

(b): Saba Shamim, Shakeel Ahmad, Rehan Ahmad Khan (2021). Blast Vulnerability of Multi-Storey Masonry Infill Reinforced Concrete Frames. Civil Engineering and Architecture, 9(3), 853 - 868. DOI: 10.13189/cea.2021.090327.

Copyright $\mathrm{C} 2021$ by authors, all rights reserved. Authors agree that this article remains permanently open access under the terms of the Creative Commons Attribution License 4.0 International License

\begin{abstract}
The prototype or experimental study of blast effect on structures is not always possible due to high risk of life and environmental wellbeing. However, advancement in computational science had made it possible to solve such complex and risky problems. Researchers in the past few decades have presented ample computational and numerical studies on blast effect on masonry structure using deterministic approach. The studies have neglected the effect of various uncertainties that may perhaps occur during an actual blast scenario. Therefore, in present study probabilistic Finite Element (FE) analysis was performed on three statistically stable masonry infill RC (Reinforced Concrete) frames having single $(\mathrm{G}+0)$, two $(\mathrm{G}+1)$ and three $(\mathrm{G}+2)$ storey levels respectively to arrive at the blast fragility curves. The probability of failure was computed based on the inelastic tension damage curves developed for the masonry. The effect of scaled distance and different storey levels on blast vulnerability of masonry infill RC frame walls are investigated through these fragility curves. The results indicate a noteworthy effect of scaled distance and storey levels on the blast resistance of the structure. Frame G+0 is found to be comparatively more vulnerable against the blast load effect than other multi-storey frames. The critical value of scaled distance $\left(Z_{\text {critical }}\right)$ corresponding to $\mathrm{PF} 90 \%$ in panel P1 was found as $6.67 \mathrm{~m} / \mathrm{kg}^{1 / 3}, 4.81 \mathrm{~m} / \mathrm{kg}^{1 / 3}$ and $4.66 \mathrm{~m} / \mathrm{kg}^{1 / 3}$ respectively of frames $\mathrm{G}+0, \mathrm{G}+1$ and $\mathrm{G}+2$; in panel P2 was found as $4.3 \mathrm{~m} / \mathrm{kg}^{1 / 3}$ and $4.6 \mathrm{~m} / \mathrm{kg}^{1 / 3}$ respectively of frames $\mathrm{G}+2$ and $\mathrm{G}+3$ and; in panel $\mathrm{P} 3$ was found as $4.32 \mathrm{~m} / \mathrm{kg}^{1 / 3}$ of frame G+3. It is also observed that $\mathrm{RC}$ frame is negligibly affected with respect to the masonry
\end{abstract}

panel in terms of blast load mitigation.

Keywords Blast, FE Analysis, Masonry Infill, Scaled Distance, Fragility Curves

\section{Introduction}

Masonry infill frames can be very frequently seen in all types of low, medium and high-rise structures over entire world. The choice of masonry infill is justifiable because of its low cost, easy availability, excellent heat and acoustic insulation and good aesthetic appearance. Masonry constructions work incredibly great under static conditions but when subjected to dynamic forces (such as, earthquake, wind, impact or blast) they show poor resistance against such loading environment. Laboratory and prototype study of masonry subjected to earthquake, wind and impact is relatively easy. However, the experimental study of masonry under the action of blast phenomenon is quiet a risky and restrictive work area to perform although; it has been studied by few researchers in the past $[5,28,32]$. However, the computational advancement has provided softwares like LS-DYNA, ABAQUS, CONWEP etc. that can effectively simulate blast vulnerability.

Yasser et al. [34] performed the finite element blast analysis of a two dimensional 4-storey $\mathrm{RC}$ frame in ABAQUS. The authors suggested an alternative design (concrete filled steel tube sections) for columns when the 
frame failed completely when subjected to $1 \mathrm{~T}$ explosive (TNT) at 5m distance. Sielicki and Lodygowski [28] examined the actual and computational action of blast load on masonry wall. A new numerical material model for masonry phases was developed using VUMAT user subroutine in ABAQUS/EXPLICIT code implementing strain rate control. Later the results were compared with actual experimental test. Sevim and Toy [26] studied the response of two-storey RC building against different weights of TNT explosive in ANSYS AUTODYN software. The responses were compared for in terms of deformed shapes, pressure values, strain values and damage ratio showing a considerable effect of weight of explosive on RC building. Alsayed et al. [5] experimentally investigated the response of un-strengthened and strengthened (using GRPF) masonry infill RC frame wall against C-4 explosive. Also, field test results of un-strengthened as well as the strengthened walls were simulated using ANSYS-AUTODYN. The blast pressures recorded during the experiments were also validated with numerical results of analysis. The numerical models were then used for studying the effect of various parameters such as scaled distance and FRP end anchorage.All these studies have adopted the deterministic approach and have neglected the uncertainties that may occur during an actual blast.

Vulnerability of a structure against any external loading (herein, blast) can be best studied using probabilistic approach. While going through the literature, it can be seen that there is a lack of study on probabilistic analysis of Masonry against the action of blast load. However, some studies can be found on steel and reinforced concrete structures subjected to blast using probabilistic approach. Stochino et al. [30] reported probabilistic analysis of RC frame structure subjected to blast load considering the effect of seismic demand. The seismic capacity curve of RC frame was used to develop a single degree freedom model which was further considered for the probabilistic analysis using Monte Carlo simulation. The fragility curves showed that the RC frame designed for resisting highest seismic load performed most better in case of blast load. Khan et al. [13] performed the blast fragility analysis of steel structure having different configurations in SAP2000. They used Monte-Carlo simulation for generating random weight of charge (TNT) and performed the analysis for a fixed stand-off distance. Fragility curves were developed for air and surface blast at stand-off distance $10 \mathrm{~m}$ and $20 \mathrm{~m}$. Yu et al. [35] developed the blast fragility curve for RC column using Monte Carlo simulation. They found that besides the weight of charge and stand-off distance axial force significantly affects the damage in RC column. Faghihmaleki et al. [7] proposed a probabilistic framework for multi-hazard risk associated with collapse limit state of an eight-storey RC moment frame with shear wall structure, subjected to blast threats in the presence of seismic risk.The blast fragility curve has been plotted using MonteCarlo simulation for generating blast scenarios. The findings show a considerable risk; thereby, highlighting the importance of blast in designing the strategic structures in the areas of high seismic risks.

Due to lack of studies on probabilistic analysis of masonry against the action of blast the present study aims to investigate the probabilistic behaviour of three statistically stable masonry infill $\mathrm{RC}$ frames having single $(\mathrm{G}+0)$, two $(\mathrm{G}+1)$ and three $(\mathrm{G}+2)$ storey levels respectively against the action of blast. The duration of a typical blast load is usually less than a second hence, for such impulsive problems explicit analysis programs are most appropriate. Therefore, analysis has been performed using explicit Finite Element (FE) method to arrive at the blast fragility curves.The probabilistic analysis demand two basic parameters- random variables and failure criterion. The uncertainty in computation of blast load is mainly due to the weight of charge (W) and stand-off distance $(\mathrm{R})$ as reported by various scholars. Therefore, to consider both the effect simultaneously herein; scaled distance $(Z)$ has been assumed as uncertain/ random variable which is a function of $f(\mathrm{~W}, \mathrm{R})$. The failure criterion assumed in the study is based on the inelastic tension damage curve generated for the masonry on the basis of experimental results.

The main objectives of the study are: (i) to investigate the FE analysis response of masonry infill multi-storey frames in terms of displacement and stress time variations (ii) to assess the blast vulnerability of masonry infill frames by developing the fragility curve (iii) to investigate the effect of scaled distance and variation in storey levels on fragility curve of masonry infill frame.

\section{Development of Blast Load Time History Profile}

Blast explosion near a structure can cause ground induced vibrations and air induced shock fronts depending on nearness of detonation point from the ground. Hence, blast loading can be broadly classified into two; air blast and surface blast. When the point of detonation is above the ground such that it only produces air pressure which hits the target structure is called as air blast. However, if the point of detonation is on the ground level, then blast will produce air pressure which will first hit the ground surface and then the amplified pressure will hit the target structure. Hence, it can be easily stated that surface blast tend to cause more destruction as compared to air blast.

The typical pressure time history of blast load is shown in Fig.1 [31]. In reality the time $\left(\mathrm{t}_{\mathrm{a}}\right)$ required to reach $\mathrm{P}_{\mathrm{s} 0}$ is very small and taken as zero for design purpose. This side-on pressure decreases exponentially with time (as the blast wave travels away from the detonation point) till it reached the atmospheric pressure $\left(\mathrm{P}_{0}\right)$ at time $\left(\mathrm{t}_{\mathrm{a}}+\mathrm{t}_{0}\right)$ called the positive phase of the curve. After the positive phase, the pressure gets lower than the ambient pressure 
$\left(\mathrm{P}_{0}\right)$ before it again reaches $\mathrm{P}_{0}$, the later is known as the negative phase. The area under the curve signifies the impulse. The negative phase is longer than the positive phase and its minimum value is denoted as $\mathrm{P}_{\mathrm{s} 0}{ }^{-}$with duration $\mathrm{t}_{0}^{-}$. During this negative period of blast load, the structure is subjected to some amount of suction forces and which becomes the reason why sometimes during blast loading the fragments from the failures of facades are found outside a building instead in its interior.

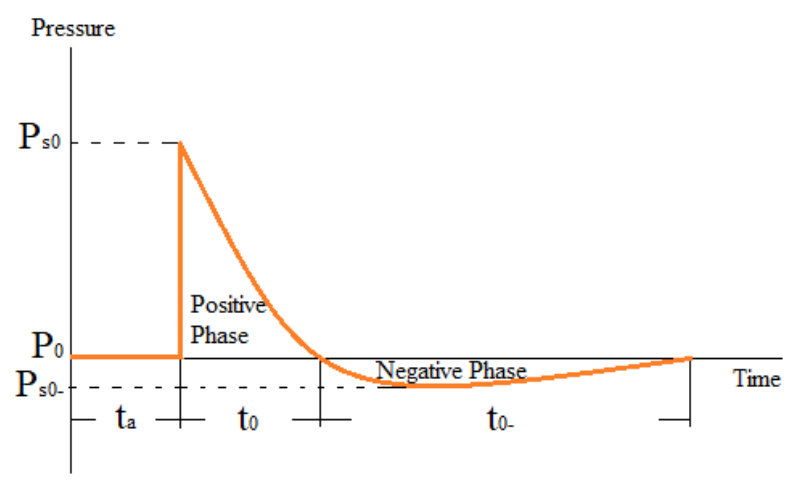

Figure 1. Blast Pressure-time history profile [31]

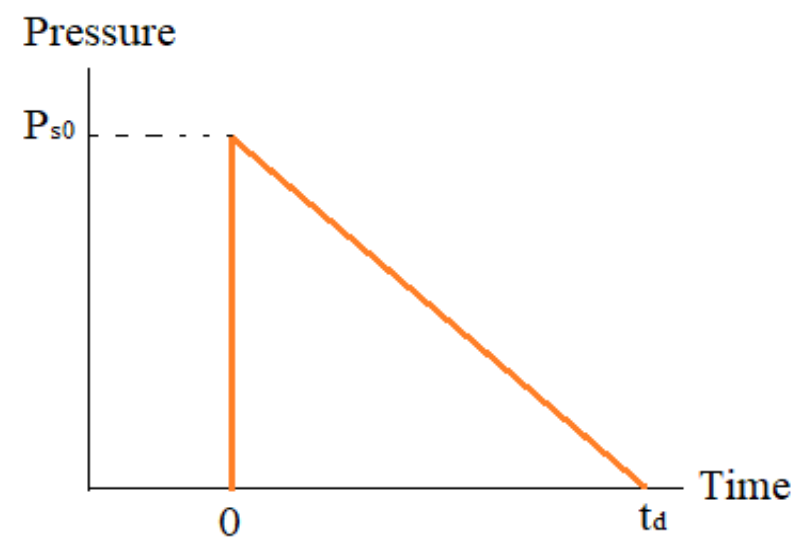

Figure 2. Idealized Pressure-time history for blast load
For purposes of exterior wall system structural design, the negative phase is typically ignored, and the positive impulse is simplified to a right triangle form as shown in Fig. 2 of idealised triangular pulse. The reason behind this idealisation lies in the fact that negative phase has a longer duration and low-pressure intensity compared to the positive phase.

According to the guidelines of Indian Standard [9] depending on the various types of building category; residential building, community building and building of post bombing importance may be designed for a bare charge of $100 \mathrm{~kg}$ TNT at standoff distances $40 \mathrm{~m}, 30 \mathrm{~m}$ and $20 \mathrm{~m}$ respectively. Shamim et al. [27] investigated the effect of angle of detonation on the masonry wall panel subjected to blast load at a fixed standoff distance $10 \mathrm{~m}$. Authors found that the most critical point of detonation is when the blast occurs in front of wall panel such that the blast wave hits the wall face normally $\left(90^{\circ}\right)$ resulting in out-of plane bending of the wall in vertical plane.

Therefore, in the present study three2-dimensional multi-storey masonry infill RC frames- $\mathrm{G}+0, \mathrm{G}+1, \mathrm{G}+2$ have been analyzed for $100 \mathrm{~kg}$ TNT charge at $20 \mathrm{~m}, 30 \mathrm{~m}$ and $40 \mathrm{~m}$ stand-off distances acting at $90^{\circ}$ on the front face of wall.Surface blast parameters for 1Tonne $(1000 \mathrm{~kg})$ explosive (Trinitrotoluene, TNT) has been given in [9]. Using the cube root scaling law given below [Equation (1) and (2)] blast time histories were determined for $100 \mathrm{Kg}$ TNT at standoff distances $20 \mathrm{~m}, 30 \mathrm{~m}$ and $40 \mathrm{~m}$ from the code.

$$
\begin{aligned}
\text { Scaled distance, } Z & =\frac{\text { Actualdistance }}{W^{1 / 3}} \\
\text { Scaled time, } t_{d} & =\frac{\text { Actualtime }}{W^{1 / 3}}
\end{aligned}
$$

where, $\mathrm{W}=$ yield of explosion in equivalent weight of the reference explosive measured in Tonnes.

The idealized blast pressure time histories computed using [9] are shown in Fig.3.

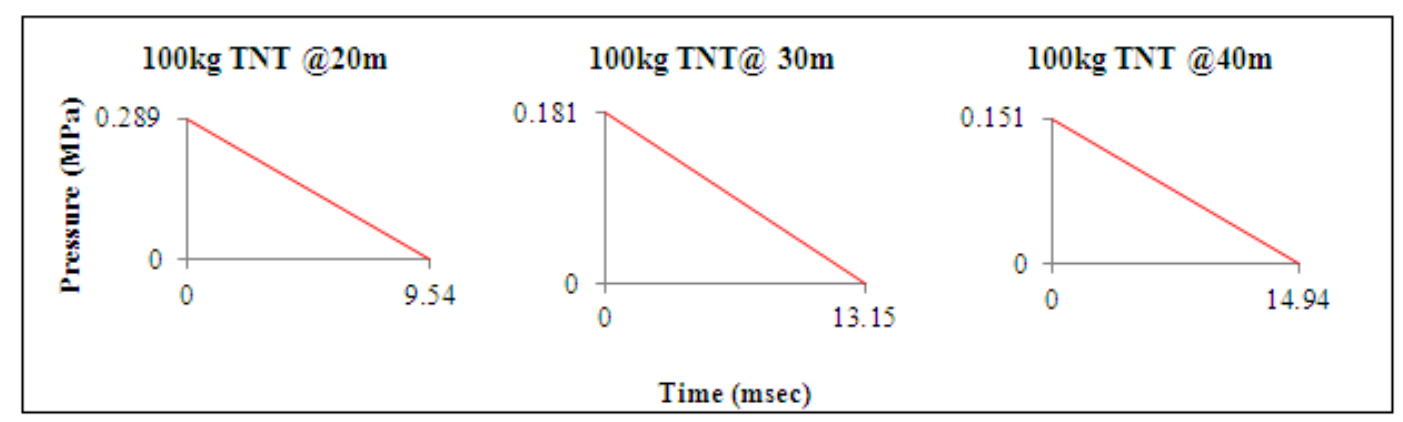

Figure 3. Idealized Pressure-time history generated from Indian Standard [9] 


\section{Description of the Multi-Storey Frames}

Table 1. Material properties

\begin{tabular}{|c|c|c|c|}
\hline $\begin{array}{c}\text { Material } \\
\text { Properties }\end{array}$ & $\begin{array}{c}\text { Density, } \\
\gamma\left(\mathrm{kg} / \mathrm{m}^{3}\right)\end{array}$ & $\begin{array}{c}\text { Modulus of } \\
\text { elasticity, } \\
\mathrm{E}(\mathrm{MPa})\end{array}$ & $\begin{array}{c}\text { Poisson's ratio, } \\
v\end{array}$ \\
\hline Masonry & 2100 & 3000 & 0.20 \\
\hline Concrete & 2400 & 22000 & 0.15 \\
\hline Steel & 8050 & 200000 & 0.30 \\
\hline
\end{tabular}

Statistically stable masonry infill RC frames- $\mathrm{G}+0, \mathrm{G}+1$ and $\mathrm{G}+2$, considered for the numerical study are shown in Fig.4. The dimension of the masonry panel is $3000 \mathrm{~mm} x$ $3000 \mathrm{~mm} \times 230 \mathrm{~mm}$ and cross-section of the RC frame is
$300 \mathrm{~mm} \times 300 \mathrm{~mm}$. The details of the reinforcement in the $\mathrm{RC}$ frames are shown in Fig.4. The material properties of masonry, concrete and steel are given in Table 1.

Further, for the application of blast load in present study, radial distance (R', R" and R"' see, Fig.5) of each masonry panel from the point of detonation has been considered for computing the blast pressure-time pulse. Therefore, due to this assumption, the pressure distribution acting on the front face of each panel would be as shown in Fig.5i.e., the pressure acting on each storey level will decrease along the height of structure (pressure is inversely proportional to distance) satisfying the condition given in (3);

$$
\begin{gathered}
P_{r 0}=P_{r 0}^{1}+P_{r 0}^{2}, f \operatorname{for}(G+1) \\
P_{r 0}=P_{r 0}^{1}+P_{r 0}^{2}+P_{r 0}^{3}, f \operatorname{for}(G+2)
\end{gathered}
$$
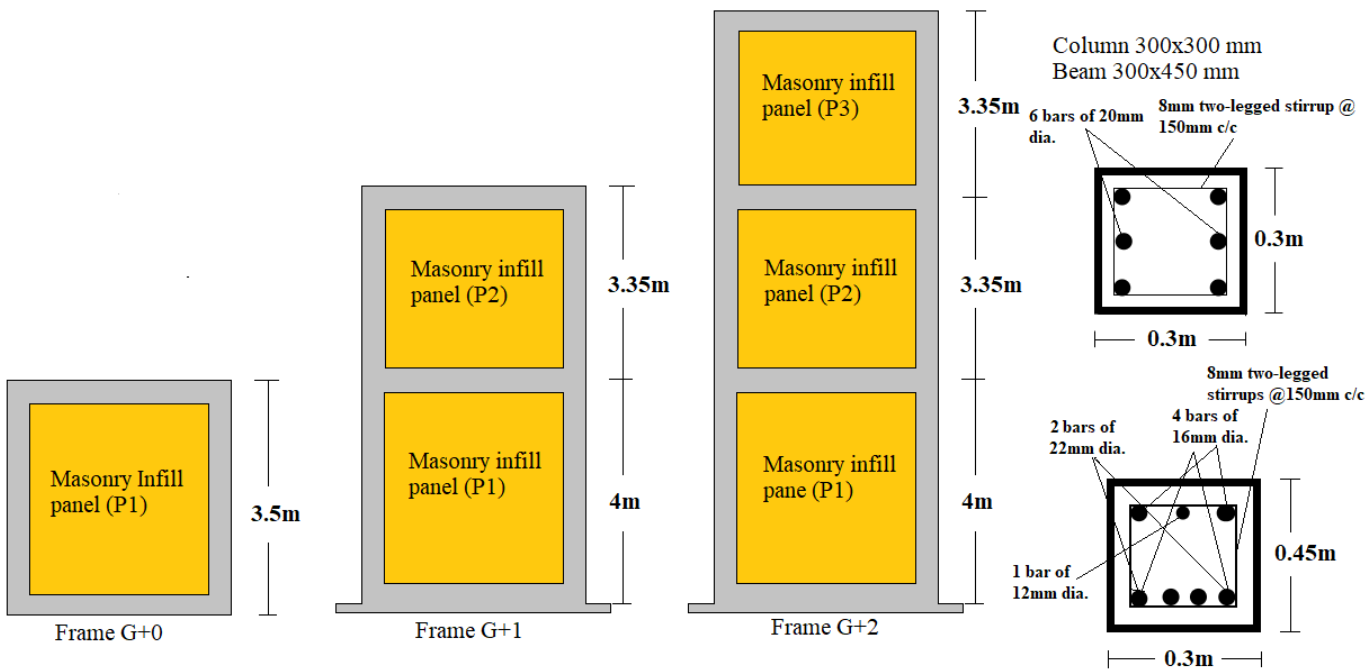

Figure 4. Details of masonry infill RC frames taken for the numerical study

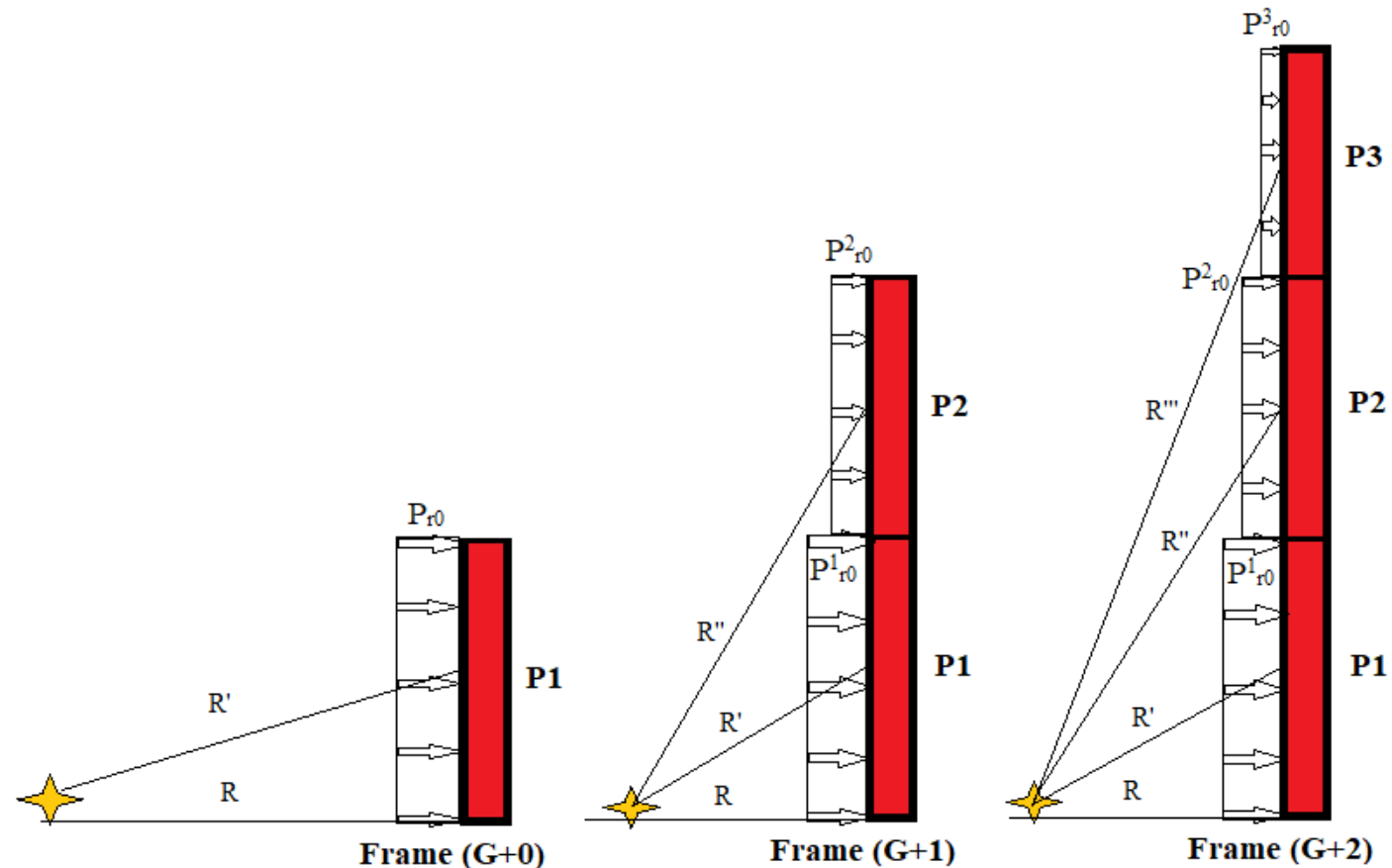

Figure 5. Blast Pressure distribution along various storey levels 


\section{Non-linear Model of the Wall}

Masonry work consists of consecutive brick and mortar layers laid in various bond patterns like; English bond, Flemish bond, Stretcher bond, Header bond etc. Nevertheless, Li et al. [16] found no significant change in blast response of wall due to variation in these bond patterns. However, to numerically study the authentic behavior of masonry detailed-micro modeling approach [2, $8,14]$ should be adopted. But, since the approach demands extensive run time in softwares therefore, macro modeling approach is more preferable when both time and accuracy are need of the problem. Herein, masonry wall panel has been modelled homogenously using macro-modelling method $[6,10,17,18,24]$ in an Explicit solver (ABAQUS 6.14). The material non-linearity in masonry and concrete has been modelled using Concrete Damaged Plasticity (CDP). This plasticity criterion is based on the models proposed by Lee and Fenves [15] and Lubliner et al. [19]. The CDP criterion is used for defining non-linearity in quasi-brittle materials like concrete, mortar, rock, ceramic etc. However, smeared crack masonry has also been modelled using CDP criterion by [20] and [33].

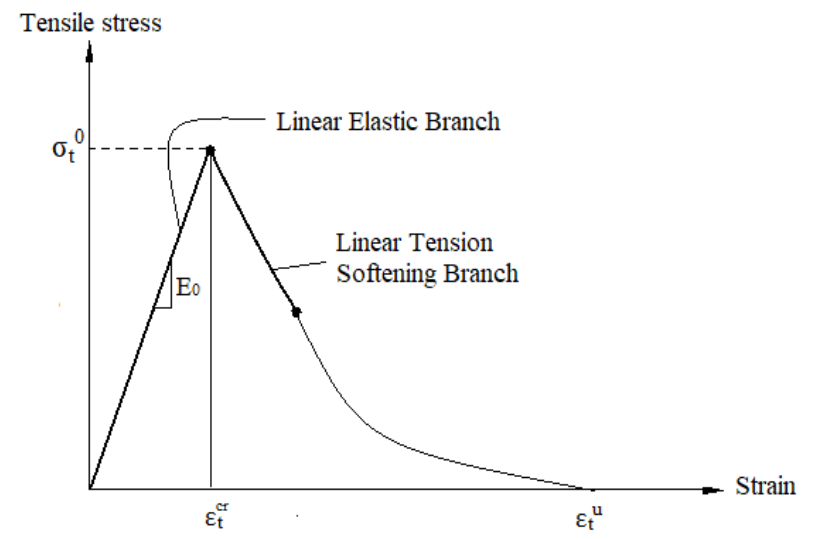

Figure 6. Stress-strain behaviour of brittle material under uniaxial tension

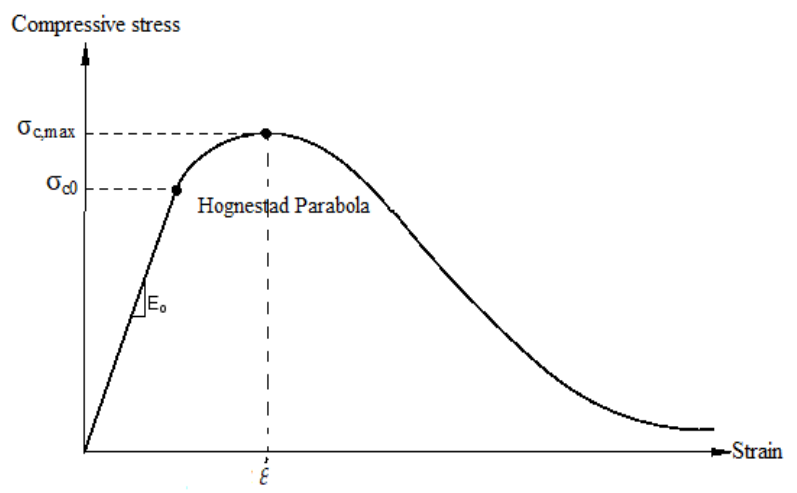

Figure 7. Stress-strain behaviour of brittle material under uniaxial compression
Masonry wall when subjected to any lateral force produces bending in vertical/horizontal plane depending on the support condition [3]. However, the failure mechanism is mainly governed by tensile cracking and compression crushing. ABAQUS [1] user manual defines the uniaxial tensile and compressive stress-strain behaviour of quasi-brittle material like; concrete outside the elastic limit. These stress-strain curves are shown in Fig. 6 and Fig. 7.

The stress-strain curve under uniaxial tension follows a linear-elastic relationship until the failure stress $\left(\sigma_{t 0}\right)$ is reached. This failure stress corresponds to the inception of micro-cracking in the material. Further, the micro-cracks tend to open wider and are represented by a softening stress-strain response thereby, inducing localized strain in material/structure. It is assumed that the softening response will tend to reduce the stress nearly to zero at ultimate strain $\left(\varepsilon_{t}^{u} \sim 10 \varepsilon_{t}^{c r}\right)$. Nayal and Rasheed [22] have defined three control points for establishing the softening behaviour of concrete which has been adopted in the present study. However, linear softening response in masonry is given by (4)[4],

$$
\sigma_{t}=\left\{\begin{array}{c}
\sigma_{t 0}\left(1-\frac{\varepsilon_{t}-\varepsilon_{t}^{c r}}{\varepsilon_{t}^{u}-\varepsilon_{t}^{c r}}\right), \varepsilon_{t}^{c r} \leq \varepsilon_{t}<\varepsilon_{t}^{u} \\
0, \varepsilon_{t}=\varepsilon_{t}^{u}
\end{array}\right.
$$

Now, under uniaxial compression the stress-strain relationship is linear-elastic until initial yield stress, $\sigma_{\mathrm{c} 0}$ is reached. The limiting value of $\sigma_{\mathrm{c} 0}$ has been assumed to be 0.33 [12] and 0.4 [21] times $\sigma_{c, \text { max }}$ for masonry and concrete respectively. Further, in the plastic regime the response is typically characterized by stress hardening followed by strain softening beyond the ultimate stress, $\sigma_{\mathrm{c}, \max }$ (corresponding to strain $\varepsilon$ ). The behaviour in plastic regime can be defined by the equation of a Hognestad parabola (5) given by,

$$
\frac{\sigma_{c}}{\sigma_{c, \text { max }}}=2\left(\frac{\varepsilon}{\grave{\varepsilon}}\right)-\left(\frac{\varepsilon}{\grave{\varepsilon}}\right)^{2}
$$

Also, the strain softening response refers to the stiffness degradation and is characterized by two damage parameters; tension damage $\left(\mathrm{d}_{\mathrm{t}}\right)$ and compression damage $\left(d_{c}\right)$ which are assumed to be function of plastic strain, temperature $(\theta)$ and field variables $\left(f_{i}\right)$ as given in Equation (6) and (7),

$$
\begin{aligned}
d_{c} & =d_{c}\left(\varepsilon_{c}^{p}, \theta, f_{i}\right) \\
d_{t} & =d_{t}\left(\varepsilon_{t}^{p}, \theta, f_{i}\right)
\end{aligned}
$$

where, $\varepsilon_{\mathrm{c}}^{\mathrm{p}}$ and $\varepsilon_{\mathrm{t}}^{\mathrm{p}}$ are compressive plastic strain and tensile plastic strain respectively. The damage parameters $d_{t}$ and $\mathrm{d}_{\mathrm{c}}$ can take values from 0 to 1 where; 0 represents the undamaged state while 1 represents total collapse. Therefore, stress-strain relationship in term of damage parameters may be given as in Equation (8) and (9);

$$
\sigma_{c}=\left(1-d_{c}\right) E_{0}\left(\varepsilon_{c}-\varepsilon_{c}^{p}\right)
$$




$$
\sigma_{t}=\left(1-d_{t}\right) E_{0}\left(\varepsilon_{t}-\varepsilon_{t}^{p}\right)
$$

Where, $\mathrm{E}_{0}$ is the linear-elastic modulus/stiffness. Therefore, the model assumes degradation in elastic stiffness given in Equation (10) and (11);

$$
\begin{aligned}
& E_{c}=E_{0}\left(1-d_{c}\right) \\
& E_{t}=E_{0}\left(1-d_{t}\right)
\end{aligned}
$$

The static compressive strength (in MPa)/peak strain for masonry [23] and concrete [11] were taken as $3.58 / 0.0018$ and $50.5 / .0015$ respectively whereas, tensile strength has been considered as $0.21 \mathrm{MPa}$ and $2.65 \mathrm{MPa}$ respectively. The developed dynamic curves for masonry and concrete are shown in Table 3 wherein; Dynamic Increase Factor (DIF) equal to 1.2 [16] and 1.19 [31] has been assumed for strength of masonry and concrete respectively in both tension and compression.

Non-linearity in steel reinforcement has been modelled using Classical Metal plasticity (CMP) model based on elasto-plastic strain hardening. DIF for steel has been assumed to be 1.17 [32]. The non-linear properties of masonry, concrete and steel are given in Table 2 and
Table 4 respectively. For masonry the typical measured values of coefficient of dilatancy $(\tan \psi)$ are in the range $0.1-0.7$ depending on the roughness of the unit surface [25] i.e., $\Psi=6^{\circ}-50^{\circ}$. Therefore, in present study the dilation angle has been calibrated and $\psi=32^{\circ}$ has been adopted to get the best validation curves (see Fig.9). The value of $\psi$ for concrete has been adopted from literature [23]. The other CDP parameters like; eccentricity; $\mathrm{f}_{\mathrm{b} 0} / \mathrm{f}_{\mathrm{c} 0 \text {, }}$ $\mathrm{K}$ and viscosity have been assumed to take the default values [1].The contact between the masonry surface and $\mathrm{RC}$ frame has been modelled using penalty contact mechanism having coefficient of friction $\mu=0.8$ [23]. The Reinforcement steel has been considered to be 'embedded' in the concrete material.

Table 2. Non-linear Material Properties

\begin{tabular}{|c|c|c|c|c|c|}
\hline $\begin{array}{c}\text { Inelastic } \\
\text { Properties }\end{array}$ & $\begin{array}{c}\text { Dilation } \\
\text { angle }\end{array}$ & Eccentricity & $\mathrm{f}_{\mathrm{b} 0} / \mathrm{f}_{\mathrm{c} 0}$ & $\mathrm{~K}$ & Viscosity \\
\hline Masonry & $\begin{array}{c}32^{\circ} \\
\text { (calibrated) }\end{array}$ & 0.1 & 1.16 & 0.667 & 0 \\
\hline Concrete & $\begin{array}{c}38^{\circ} \\
{[23]}\end{array}$ & 0.1 & 1.16 & 0.667 & 0 \\
\hline
\end{tabular}

Table 3. CDP Parameters

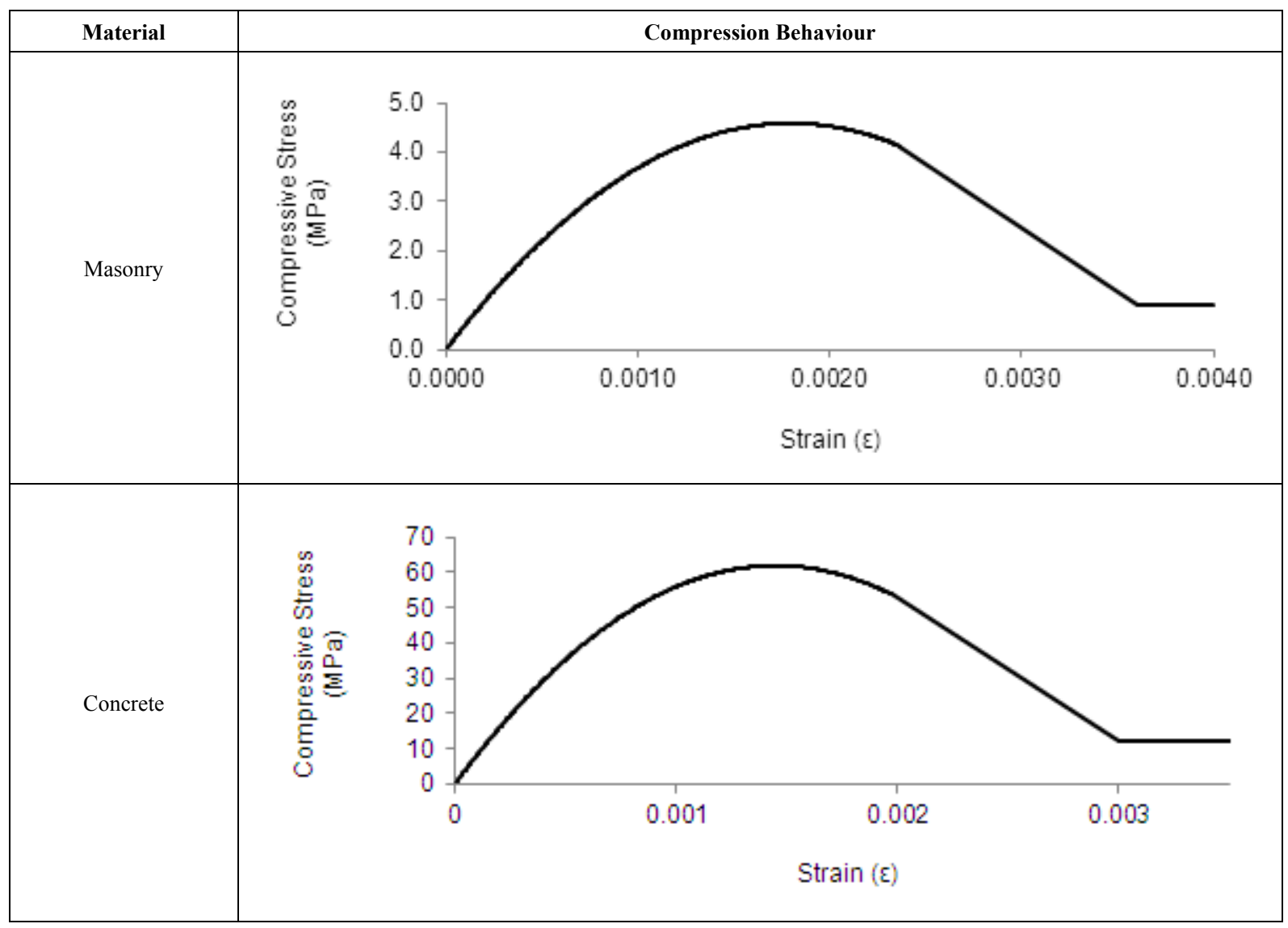


Table 3 Continued

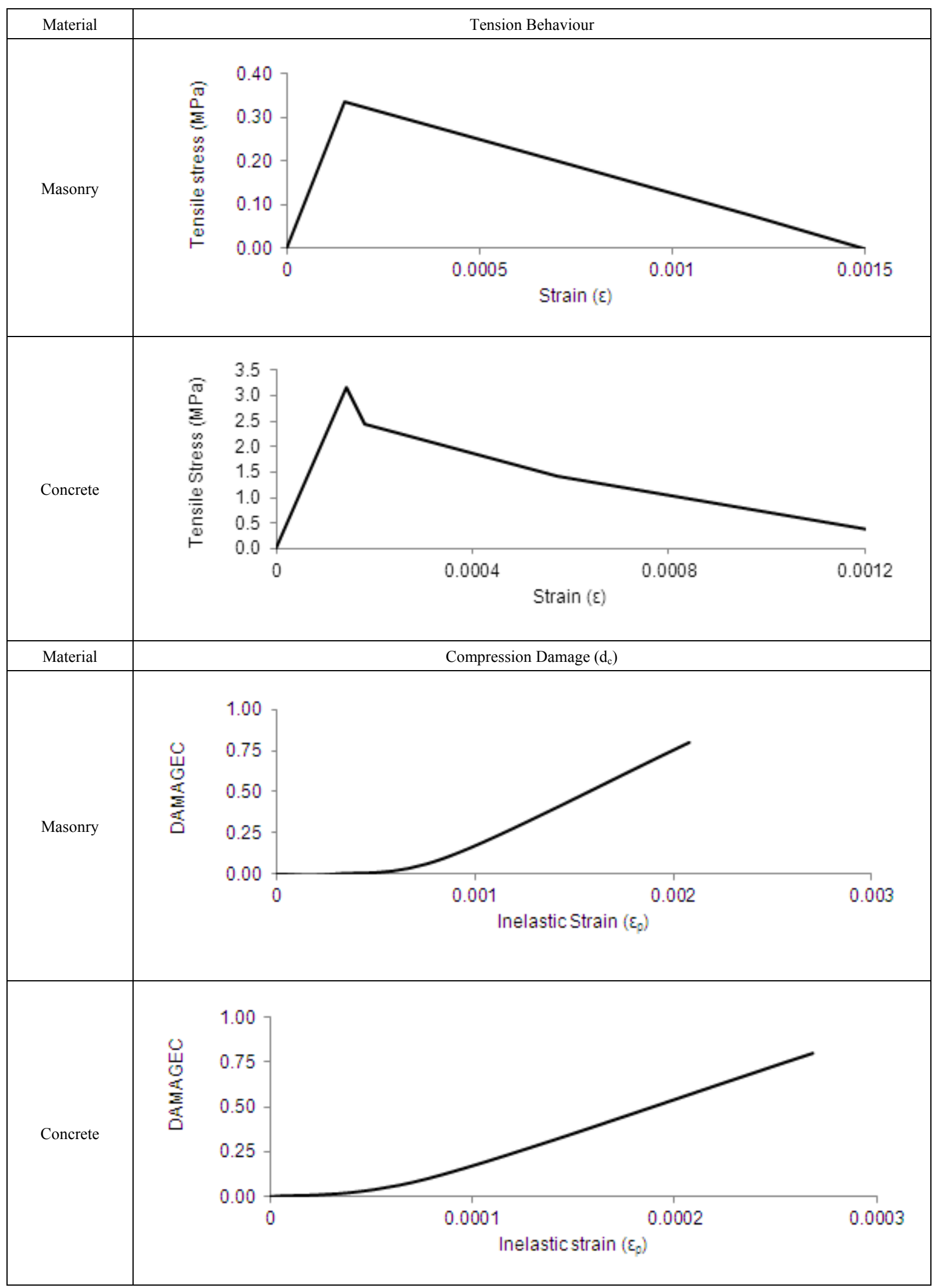


Table 3 continued

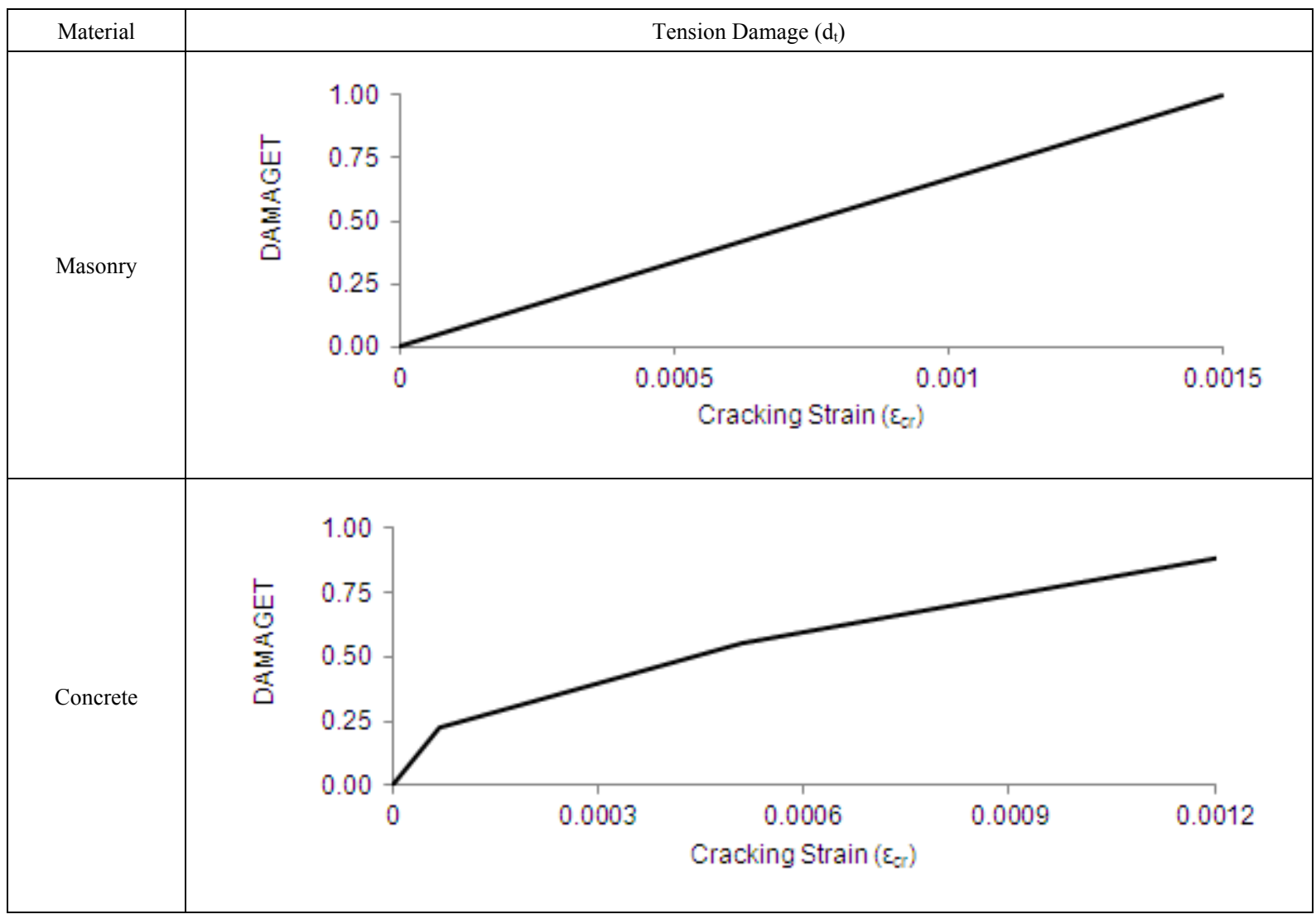

Table 4. Inelastic Properties of Steel [23]

\begin{tabular}{|c|c|}
\hline Yield Stress (MPa) & Plastic Strain \\
\hline 415 & 0.000 \\
\hline 415 & 0.007 \\
\hline 712 & 0.072 \\
\hline
\end{tabular}

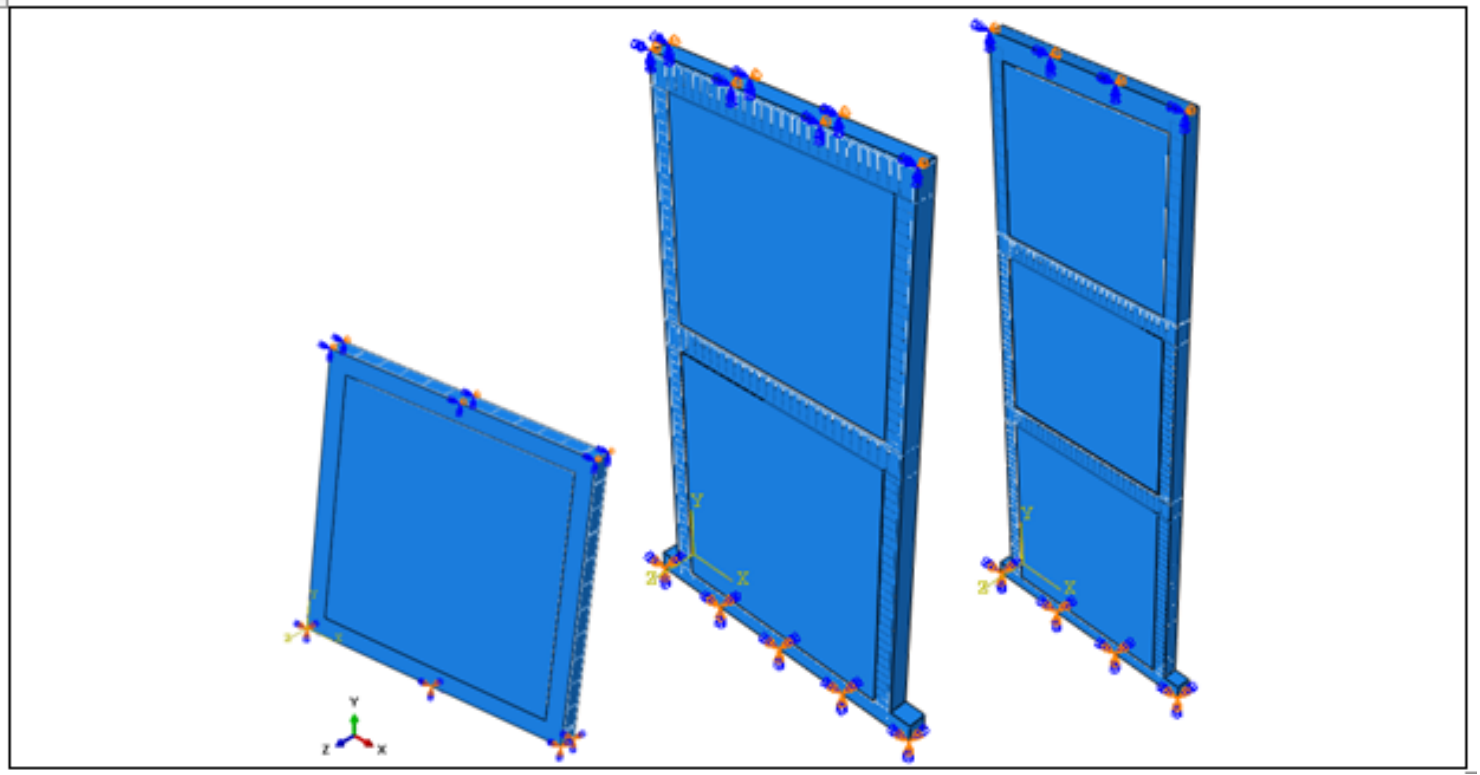

Figure 8. Three-dimensional models developed in FE explicit solver for $\mathrm{G}+0, \mathrm{G}+1$ and $\mathrm{G}+2$ frames respectively (left to right) 
The models developed using FE solver are shown in Fig.8. Masonry infill frames- $\mathrm{G}+0, \mathrm{G}+1$ and $\mathrm{G}+2$ have been discretised using $100 \mathrm{~mm}$ mesh sizes respectively on the basis of mesh convergence test. The base of the wall has been restrained in all three directions (Fixed) whereas; the top of the wall has been restrained in the direction of the applied load (z- direction). The thickness of wall in all the frames is $230 \mathrm{~mm}$. All the three frames are stable under static (gravity) load.

\section{Results of Finite Element Analysis}

The frames $\mathrm{G}+0, \mathrm{G}+1, \mathrm{G}+2$ have been subjected to surface blast of $100 \mathrm{~kg}$ TNT (Trinitrotoluene) charge at standoff distances (R) $-20 \mathrm{~m}, 30 \mathrm{~m}$ and $40 \mathrm{~m}$ respectively. The dynamic responses of frames have been investigated in terms of displacement-time and stress-time variations.

\section{A. Frame G+o}

The blast response of frame $\mathrm{G}+0$ investigated previously in literature [23] for $100 \mathrm{~kg}$ TNT at $\mathrm{R}=20 \mathrm{~m}$, $30 \mathrm{~m}$ and $40 \mathrm{~m}$ respectively has been compared with the present numerical model (CDP). The peak displacement values have been found to be fairly comparable with extremely minor discrepancy due to difference in the adopted numerical approaches. Nevertheless, Fig.9 represents a good agreement between the models in terms of displacement-time response thereby, validating the present numerical approach.

The Displacement-time and Stress-time variation for $100 \mathrm{~kg}$ TNT at $20 \mathrm{~m}, 30 \mathrm{~m}$ and $40 \mathrm{mstand}$-off distances are shown in Fig.10. The masonry panel suffers out-of-plane bending in vertical plane resulting in maximum deflection at the centre of masonry panel. However, the damage intensity (both displacement and stress) reduces with increase in the standoff distance. The wall experienced a maximum central displacement of $235.8 \mathrm{~mm}, 75.5 \mathrm{~mm}$ and $59.9 \mathrm{~mm}$ corresponding to $100 \mathrm{~kg}$ TNT blast at $20 \mathrm{~m}, 30 \mathrm{~m}$ and $40 \mathrm{~m}$ standoff distances respectively. The maximum displacement for $100 \mathrm{~kg}$ TNT at $20 \mathrm{~m}$ was found to be greater than the thickness of wall $(>230 \mathrm{~mm})$ resulting in blow-out of masonry panel (P1).

\section{B. Frame G+1}

The frame consists of two masonry infill panels P1 and P2 at ground level and at second storey level respectively. Displacement-time and stress-time response of panels P1 and P2 have been plotted in Fig.11 and Fig.12 respectively. Peak central displacements in panel P1 were found to be $190.7 \mathrm{~mm}, 90.1 \mathrm{~mm}$ and $61.1 \mathrm{~mm}$ whereas, in panel P2 same was found to be $150 \mathrm{~mm}, 50.9 \mathrm{~mm}$ and $56.9 \mathrm{~mm}$ corresponding to $100 \mathrm{~kg}$ TNT blast at $20 \mathrm{~m}, 30 \mathrm{~m}$ and $40 \mathrm{~m}$ respectively. The maximum displacement as well as stress for panel P1 has been found to be greater than panel P2 for all the cases.

\section{Frame G+2}

Herein, the frame consists of three masonry infill panels P1, P2 and P3 at ground, first and second storey levels respectively. The maximum displacement in panel P1 was found to be $201.8 \mathrm{~mm}, 88 \mathrm{~mm}, 60.2 \mathrm{~mm}$ respectively for $20 \mathrm{~m}, 30 \mathrm{~m}$ and $40 \mathrm{~m}$ stand-off distances. Further, maximum displacement in panel P2 was found to be $187.9 \mathrm{~mm}, 88 \mathrm{~mm}, 60.2 \mathrm{~mm}$ respectively for $\mathrm{R}=20 \mathrm{~m}, 30 \mathrm{~m}$ and $40 \mathrm{~m}$. Finally, maximum displacement in pane P3 were found to be $150 \mathrm{~mm}, 80.5 \mathrm{~mm}, 55 \mathrm{~mm}$ for $\mathrm{R}=20 \mathrm{~m}$, $30 \mathrm{~m}$ and $40 \mathrm{~m}$ respectively. Similar to the $\mathrm{G}+1$ frame here also, the maximum displacement and Von Mises stress were found in bottom panel P1 for all the cases. Displacement-time and stress-time plots developed in software are shown in Fig.13, Fig.14 and Fig.15 for panels $\mathrm{P} 1, \mathrm{P} 2$ and $\mathrm{P} 3$ respectively.

Also, it is important to observe that for all the cases the time of peak displacement and stress is same confirming the effectiveness of adopted numerical simulation.

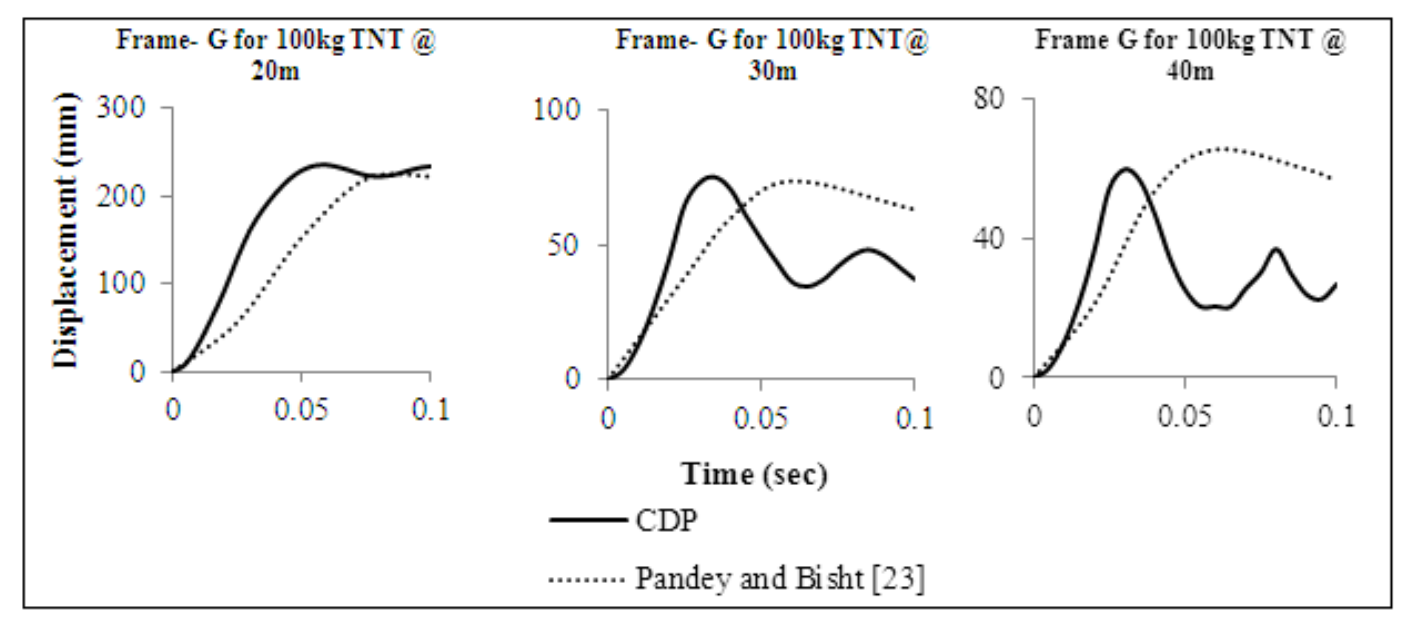

Figure 9. Validation of present numerical approach 


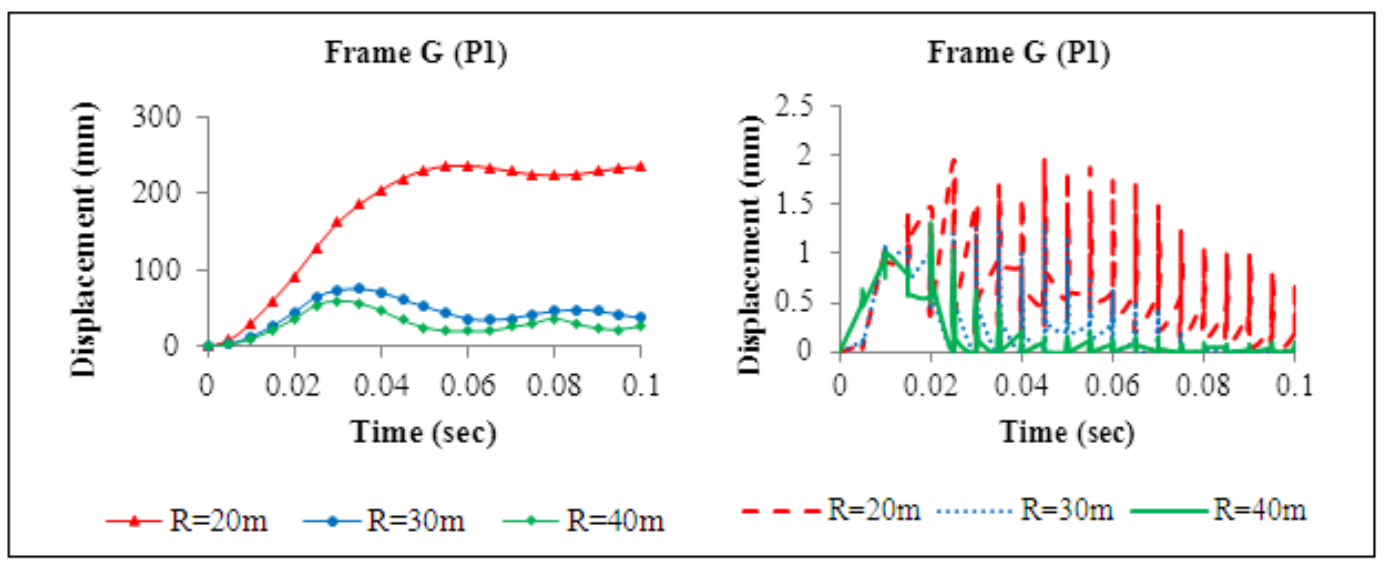

Figure 10. Displacement and stress time history for panel P1 of frame $\mathrm{G}+0$

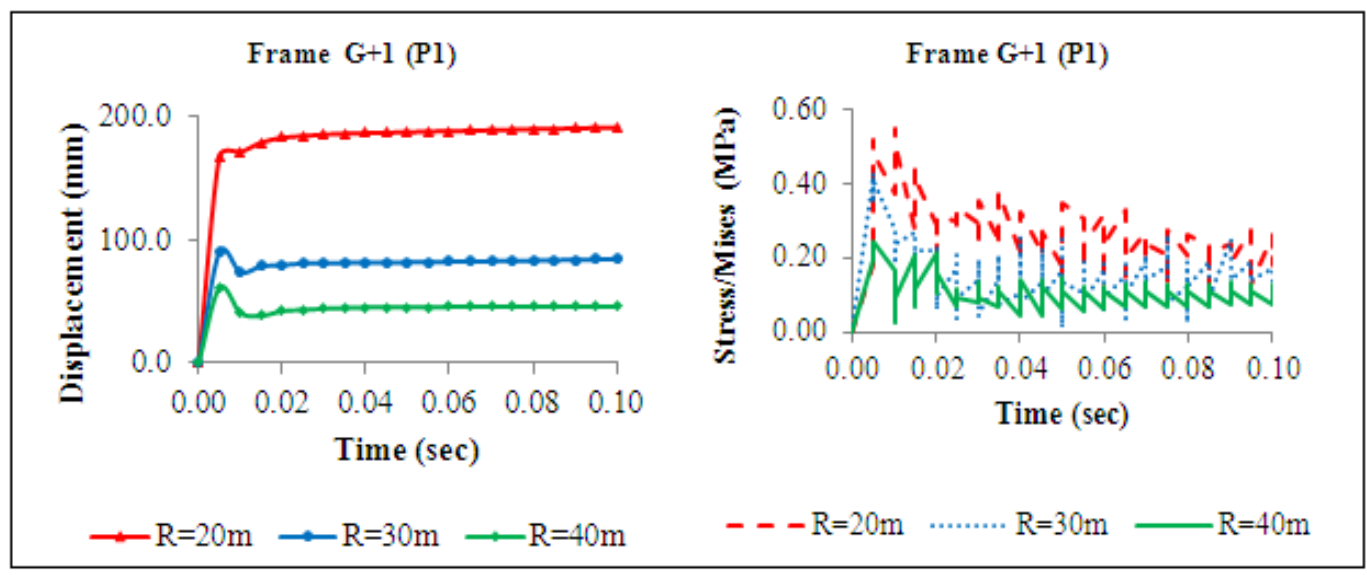

Figure 11. Displacement and stress time history for panel $\mathrm{P} 1$ of frame $\mathrm{G}+1$

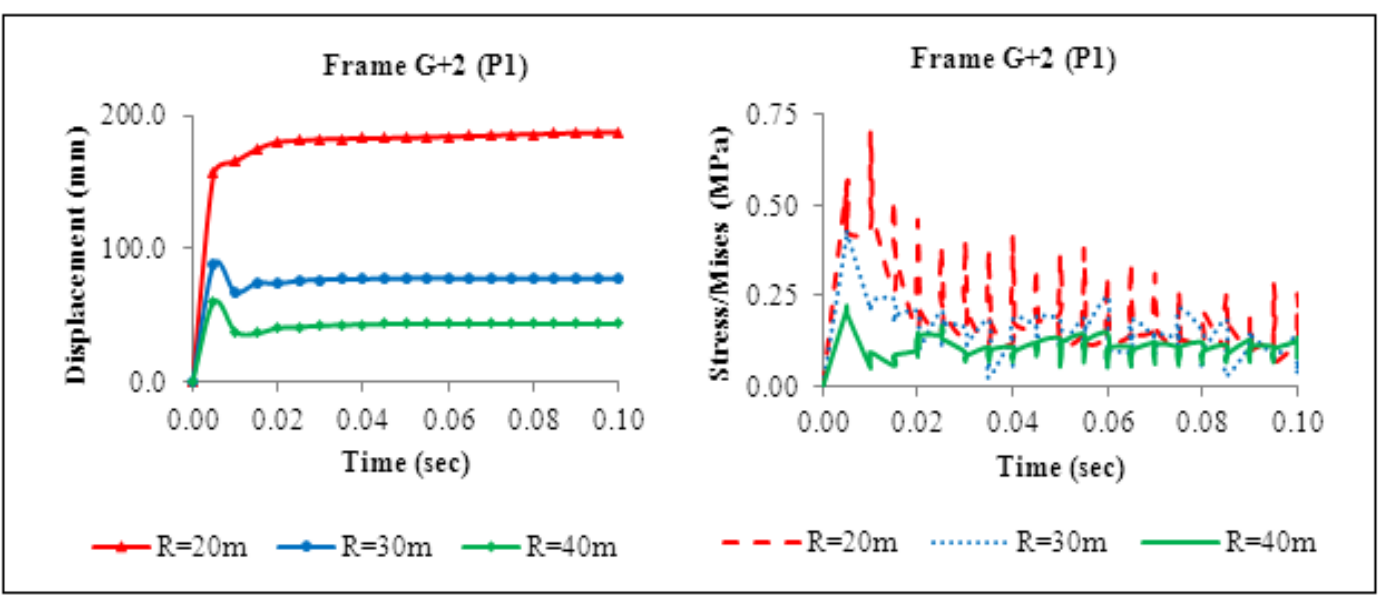

Figure 12. Displacement and stress time history for panel $\mathrm{P} 1$ of frame $\mathrm{G}+2$ 


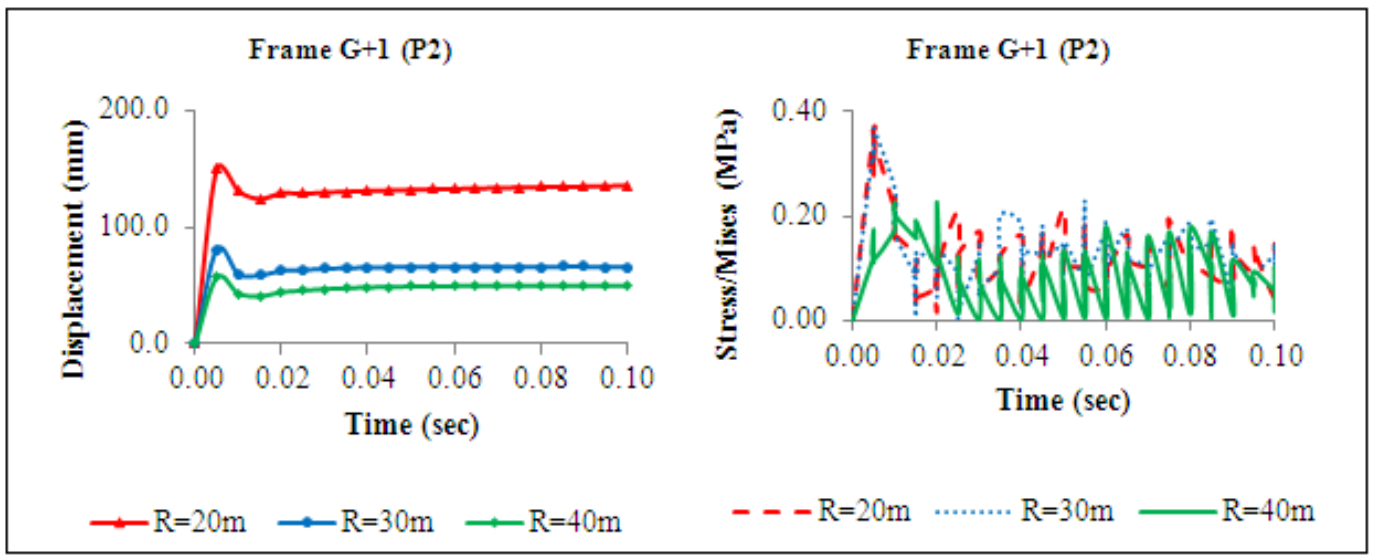

Figure 13. Displacement and stress time history for panel $\mathrm{P} 2$ of frame $\mathrm{G}+1$

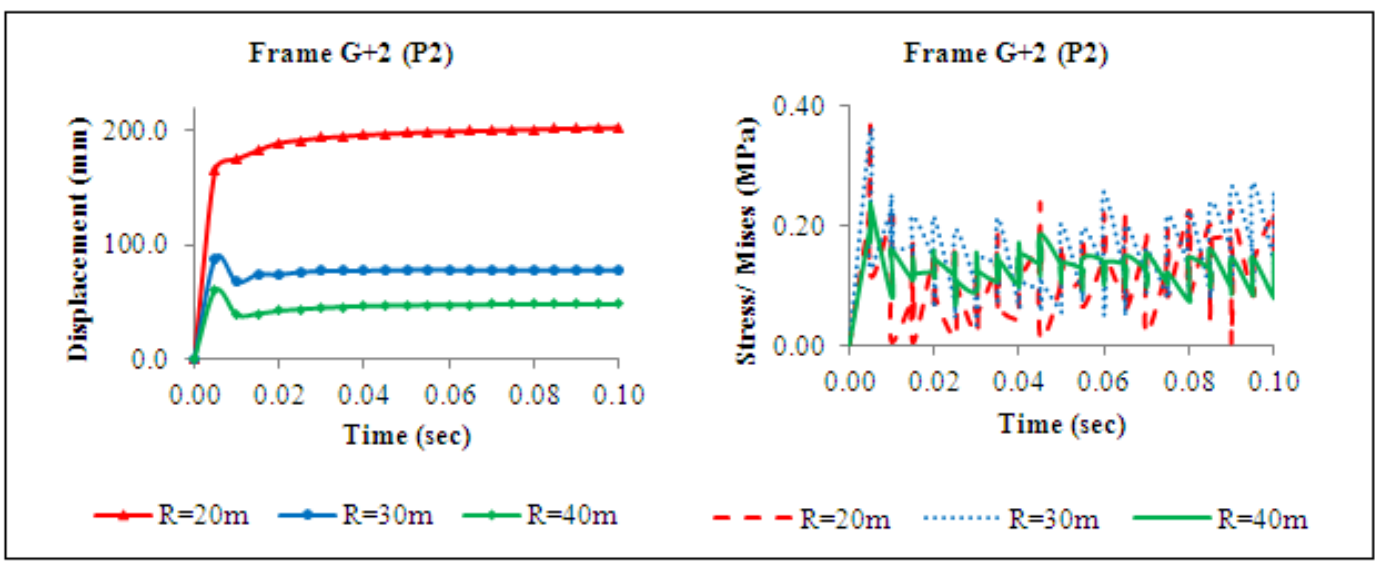

Figure 14. Displacement and stress time history for panel $\mathrm{P} 2$ of frame $\mathrm{G}+2$

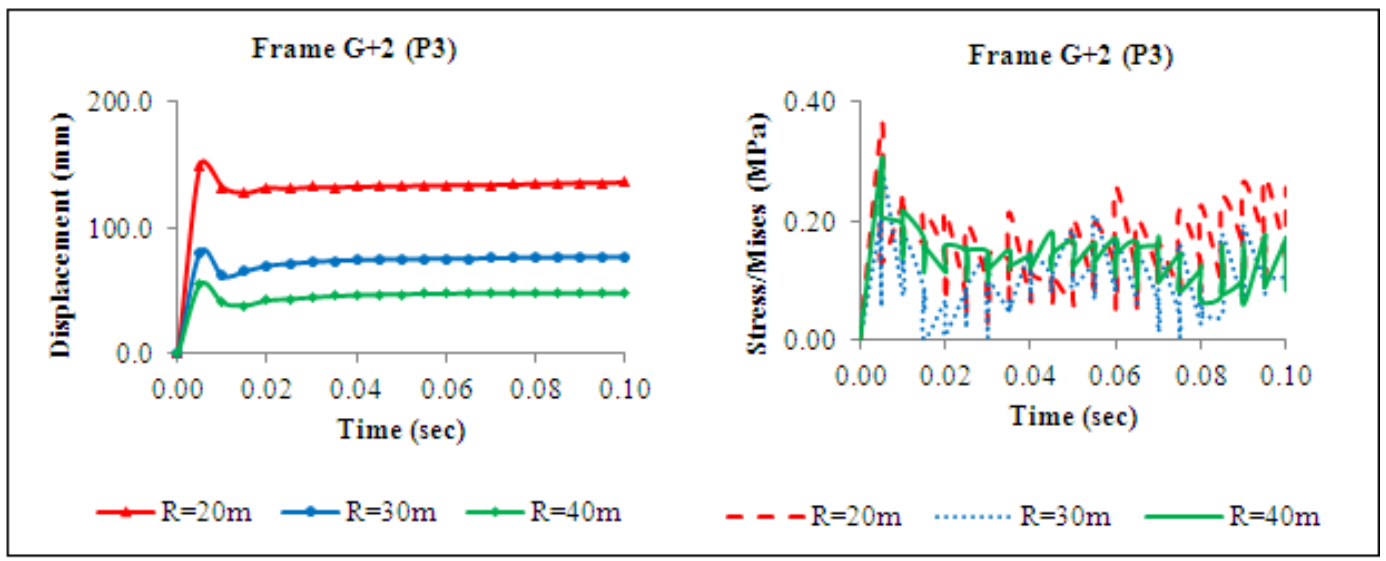

Figure 15. Displacement and stress time history for panel $\mathrm{P} 3$ of frame $\mathrm{G}+2$

\section{Fragility Assessment}

Probabilistic analysis can assess the vulnerability of structure by developing the fragility curves. The fragility curves are actually developed by performing rigorous and repetitive FE dynamic analysis considering all the possible blast cases on the structure. Therefore, a fragility curve is capable of predicting the various failure levels (low, moderate and severe) which is vital for blast mitigation of structure. Structural blast fragility describes the likelihood of damage due to uncertain blast load. The blast fragility for a structure is mathematically defined as the conditional probability of failure of the structure under specific blast load [13].

Let $C_{i}$ be the capacity of structure to resist the blast load vulnerability corresponding to the $i^{\text {th }}$ limit state. Then probability of failure $\left(\mathrm{PF}_{\mathrm{ij}}\right)$ wrt $\mathrm{i}^{\text {th }}$ limit state at the $\mathrm{j}^{\text {th }}$ blast intensity level $\left(\mathrm{I}_{\mathrm{j}}\right)$ is defined as in (12), 


$$
\mathbf{P F}_{\mathrm{ij}}=\mathbf{P}\left(\mathbf{D} \geq \mathbf{C}_{\mathbf{i}} \mid \mathbf{I}_{\mathbf{j}}\right)
$$

Where, $I_{j}$ is the $j^{\text {th }}$ blast intensity level and $D$ is the demand of structure due to uncertain parameters.

There are several parameters on which a blast scenario depends namely; stand-off distance (R), weight of charge (W), height of detonation, barrier level etc. Generally, in determining the blast fragility either weight of charge (W) or standoff (R) distance has been considered as an uncertain parameter in past studies. However, both $\mathrm{W}$ and $\mathrm{R}$ are mathematically related to each other in terms of scaled distance $(Z)$ (see equation (1)). Therefore, in present study blast intensity $I_{j}$ is represented by scaled distance $\left(Z_{\text {random }}\right)$. The random variable $Z$ has been computed for each randomly generated $\mathrm{W}$ and $\mathrm{R}$ using Monte Carlo simulation. Here, $\mathrm{W}$ has been assumed to obey normal distribution having $\mathrm{COV}=0.102[7,29,35]$ and $\mathrm{R}$ has been assumed to be Log-normally distributed having $\mathrm{COV}=0.05$ [35]. The failure criterion has been defined in terms of inelastic tension damage parameter (as discussed before, see Table 3) which is a function of cracking strain or plastic strain $\left(\varepsilon_{\mathrm{t}}^{\mathrm{p}}\right)$. Here, four damage levels have been defined based on the plastic strain value as as given below;

- Minor cracks $(\mathrm{D}<0.2)$ i.e., when less than $20 \%$ wall elements will fail due to exceeding tensile strain at limiting state- MD
Repairable Damage $(0.5>\mathrm{D} \geq 0.2)$ i.e., when more than $20 \%$ wall elements will fail due to exceeding tensile strain at limiting state- RD

- Non- repairable Damage $(0.8>\mathrm{D} \geq 0.5)$ i.e., when more than $50 \%$ wall elements will fail due to exceeding tensile strain at limiting state- NRD

- Total Collapse/Damage $(\mathrm{D} \geq 0.8)$ i.e., when more than $80 \%$ wall elements will fail due to exceeding tensile strain at limiting state- TD

The definition of these damage levels is quite subjective although the physical meaning is very apparent $(\mathrm{D} \sim \mathrm{dt})$. A more or less similar type of damage levels have been defined by Yu et al. [35] for RC structures. Based on these damage levels threshold values of $\left(\varepsilon_{t}^{p}\right)$ have been defined as shown in Fig.16. The limiting value of plastic strain was assumed for $\mathrm{dt} \geq 0.5$ because before this limit the damages have been assumed to be repairable on the basis of FE analysis.

In addition, from the results of $\mathrm{FE}$, analysis performed on masonry infill panel $\mathrm{G}+0, \mathrm{G}+1$ and $\mathrm{G}+2$; it has been witnessed that RC frame remains in undamaged state even when the masonry panel(s) has failed completely. Therefore, the fragility curve has been developed for the masonry panel alone neglecting the behaviour of RC frame. The conditional probability of failure from Equation (12) can be rewritten as,

$$
P F_{i j}=P\left(\varepsilon_{D} \geq \varepsilon_{d t \geq 0.5} \mid Z_{\text {random }}\right)
$$

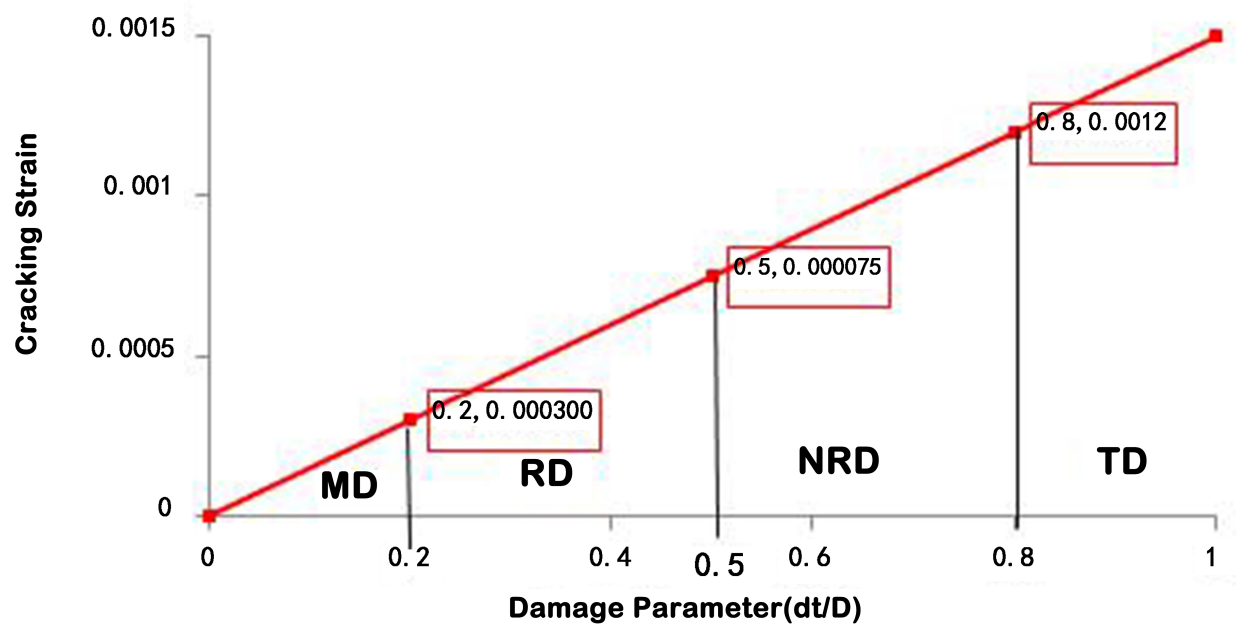

Figure 16. Four levels of Damage 


\section{A. Steps for Developing the Fragility Curve}

The steps followed in developing the fragility curves for masonry infill frames $\mathrm{G}+0, \mathrm{G}+1$ and $\mathrm{G}+2$ have been summarised below.

1) Define the strain capacity of masonry corresponding to the the $i^{\text {th }}$ limit state.

2) Use Monte Carlo (MC) simulations randomly generate $\mathrm{W}$ and $\mathrm{R}$ based on mean and standard deviation of the respective distributions.

3) From these random generated values of $\mathrm{W}$ and $\mathrm{R}$ work out the blast pressure-time history using IS code [9] meant for the random scaled distance $\left(Z_{\text {random }}\right)$.

$$
Z_{\text {random }}=\frac{R}{W^{1 / 3}}
$$

4) Analyse the frames for each simulated scenario of blast and obtain the response [i.e., the plastic strain corresponding to $\left.\mathrm{dt} \geq 0.5\left(\varepsilon_{\mathrm{d}} \geq 0.5\right)\right]$.

5) Compare the plastic strain of each element with the defined strain capacity of masonry. The masonry is considered to fail when $50 \%$ of the total elements reach the failure criterion.

6) Repeat steps (2)-(5) for $\mathrm{N}$ number of simulations considering different $Z_{\text {random. }}$ It requires 25-35 simulations for obtaining blast probability of failure using MC simulation. The PF is computed by,

$$
P F=1-\frac{N_{\text {active }}}{N}
$$

where, $\mathrm{N}_{\text {active }}=$ number of simulations when the demand was less than the capacity.

7) Develop the Fragility curve with scaled distance (Z) on $\mathrm{X}$-axis and probability of Failure $\mathrm{PF}(\mathrm{D} \geq 0.5)$ on Y-axis.

The obtained FC(s) for the masonry panels of multi-storey frame $(\mathrm{G}+1$ and $\mathrm{G}+2)$ are plotted in Fig.17. For $\mathrm{Z}=6 \mathrm{~m} / \mathrm{kg}^{1 / 3}$ the probabilities of NRD $(\mathrm{D} \geq 0.5)$ are $19.8 \%, 14.4 \%$ for P1 and P2 respectively of frame G+1 and $34.7 \%, 31.8 \%, 16.6 \%$ for $\mathrm{P} 1, \mathrm{P} 2$ and $\mathrm{P} 3$ respectively of frame G+2. Also, the FC for frame $\mathrm{P} 1(\mathrm{G}+0)$ has been compared with the $\mathrm{FC}(\mathrm{s})$ for masonry panels of $\mathrm{G}+1$ and $\mathrm{G}+2$ frames as shown inFig. 18. It has been found that for $\mathrm{Z}=6 \mathrm{~m} / \mathrm{kg}^{1 / 3}$ the probability of NRD $(\mathrm{D} \geq 0.5)$ is $92.9 \%$ for $\mathrm{P} 1(\mathrm{G}+0)$. The PF of single storey frame is higher than the multi-storey frames because the entire reflected pressure $\left(\mathrm{P}_{\mathrm{r} 0}\right)$ acts on $\mathrm{P} 1(\mathrm{G}+0)$ whereas, in multi-storey frames the pressure $\mathrm{P}_{\mathrm{r} 0}$ is assumed to be distributed on each panel (see Fig.5) such that; sum of pressure on each panel is equal to total reflected pressure $\left(\mathrm{P}_{\mathrm{r} 0}\right)$ as given in equation (3). However, the critical value of scaled distance $\left(Z_{\text {critical }}\right)$ for each masonry panel corresponds to when the PF is $90 \%$. The values of $Z_{\text {critical }}$ are given in Table 5 .

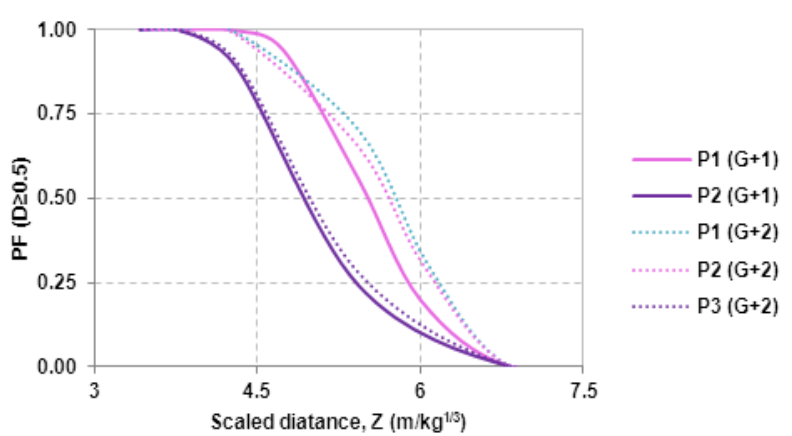

Figure 17. FC(s) for masonry panels of multi-storey frame

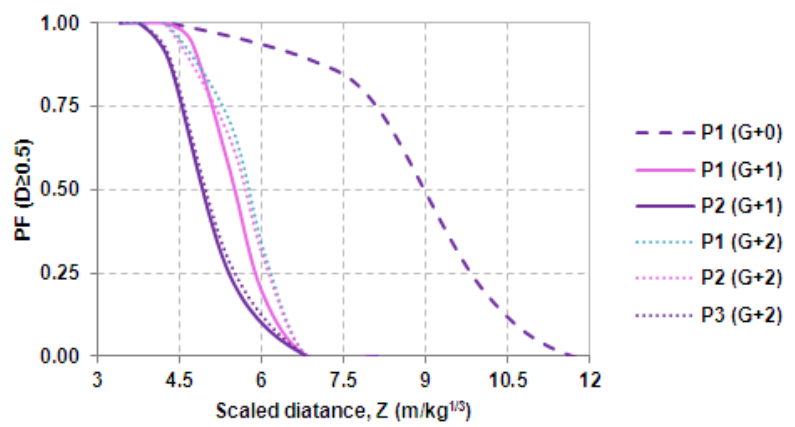

Figure 18. Comparison between masonry panel FC(s) of single and multi-storey frames

Table 5. Values of Critical Scaled Distance

\begin{tabular}{|c|c|c|}
\hline Frame & Masonry Panel & $\begin{array}{c}\mathbf{Z}_{\text {critical }} \\
\left(\mathbf{m} / \mathbf{k g}^{\mathbf{1 / 3}}\right)\end{array}$ \\
\hline \multirow{2}{*}{$\mathrm{G}+0$} & $\mathrm{P} 1$ & 6.67 \\
\hline \multirow{2}{*}{$\mathrm{G}+1$} & $\mathrm{P} 1$ & 4.81 \\
\cline { 2 - 3 } & $\mathrm{P} 2$ & 4.30 \\
\hline \multirow{2}{*}{$\mathrm{G}+2$} & $\mathrm{P} 1$ & 4.66 \\
\cline { 2 - 3 } & $\mathrm{P} 2$ & 4.60 \\
\cline { 2 - 3 } & $\mathrm{P} 3$ & 4.32 \\
\hline
\end{tabular}

\section{Conclusions}

The blast response of multistory masonry frames $(\mathrm{G}+0$, $\mathrm{G}+1$ and $\mathrm{G}+2$ ) have been investigated using FE analysis. The level of damage caused in the masonry panel(s) has been clearly explained on the basis of vulnerability/probabilistic analysis. The probabilistic curves also known as fragility curves have been developed considering scaled distance $[\mathrm{Z}=f(\mathrm{~W}, \mathrm{R})]$ as random variable. The failure criteria have been defined in terms of inelastic tensile damage level (dt) which is dependent on the cracking strain developed in the masonry. Since, the damage curve is based on the stress-strain variation of the masonry and hence, is capable in predicting the damage levels to a good accurateness. Following are the conclusions drawn from the present investigation: 
- The results of dynamic analysis have been presented for $100 \mathrm{~kg}$ TNT blast at stand-off distances, $\mathrm{R}=20 \mathrm{~m}$, $30 \mathrm{~m}$ and $40 \mathrm{~m}$ respectively for the three masonry infill frames. It has been found the displacement and stress (Mises) both decreases with increasing R. Also, it has been observed that the time of maximum displacement and stress (Von Mises) was identical thereby, proving the effectiveness of the numerical approach.

- The masonry panels failed due to excessive out-of-plane bending in vertical plane witnessing maximum deflection at the centre of masonry $\operatorname{panel}(\mathrm{s})$.

- It has been found that scaled distance act as an important parameter for mitigating blast load effect on masonry infill frames. The severity of blast increases as the scaled distance keeps on decreasing.

- The critical value of scaled distance ( $\left.Z_{\text {critical }}\right)$ corresponding to PF $90 \%$ in panel P1 was found as $6.67 \mathrm{~m} / \mathrm{kg}^{1 / 3}, 4.81 \mathrm{~m} / \mathrm{kg}^{1 / 3}$ and $4.66 \mathrm{~m} / \mathrm{kg}^{1 / 3}$ respectively of frames $\mathrm{G}+0, \mathrm{G}+1$ and $\mathrm{G}+2$

- In panel P2 the critical value of scaled distance was found as $4.3 \mathrm{~m} / \mathrm{kg}^{1 / 3}$ and $4.6 \mathrm{~m} / \mathrm{kg}^{1 / 3}$ respectively of frames $\mathrm{G}+2$ and $\mathrm{G}+3$.

- In panel P3 the critical scaled distance was found as $4.32 \mathrm{~m} / \mathrm{kg}^{1 / 3}$ of frame $\mathrm{G}+3$.

- In addition, it has also been witnessed that the RC frame remains unaffected or least critical against the blast load mitigation.

\section{Future Scope}

In present study single and multi-storey ( 2 and 3 levels) portal frames (single bay) have been considered having infill masonry however, more storey levels may be considered and also number of bay may be increased.

\section{Declaration}

Authors hereby declare no conflict of interest.

\section{Nomenclature}

CDP, Concrete damaged plasticity

G, Ground Level

MC, Monte Carlo

P1/P2/P3, Masonry panels 1/2/3

PF, Probability of failure

$\mathrm{RC}$, Reinforced concrete

$\mathrm{R}$, Stand-off distance

TNT, Trinitrotoluene

$\mathrm{W}$, Weight of explosive/charge

$\mathrm{Z}$, Scaled distance

$\mathrm{C}_{\mathrm{i}}$, Capacity of $i^{\text {th }}$ limit state
$\mathrm{D}$, Demand

$\mathrm{d}_{\mathrm{t}} / \mathrm{d}_{\mathrm{c}}$, Damage parameter $(\mathrm{t}=$ tension and $\mathrm{c}=$ compression $)$

$\mathrm{E} / \mathrm{E}_{0}$,Modulus of elasticity

$\mathrm{E}_{\mathrm{t}} / \mathrm{E}_{\mathrm{c}}$, Modulus of elasticity $(\mathrm{t}=$ tension and $\mathrm{c}=$ compression)

$\mathrm{f}_{\mathrm{i}}$, Field variables

$\mathrm{I}_{\mathrm{j}}$, Intensity of blast

$\mathrm{P}_{0}$, Atmospheric pressure

$\mathrm{P}_{\text {so-, }}$ Peak negative pressure

$\mathrm{P}_{\text {so }}$, Peak static overpressure

$t_{0-}$, Negative phase duration

$\mathrm{t}_{\mathrm{a}}+\mathrm{t}_{0}$ Positive phase duration

$\mathrm{t}_{\mathrm{a}}$, arrival time

$t_{d}$, Duration of idealized pulse

$\gamma$, Density of material

$\varepsilon_{\mathrm{t}} / \varepsilon_{\mathrm{c}}$,Elastic strain $(\mathrm{t}=$ tension and $\mathrm{c}=$ compression $)$

$\varepsilon_{\mathrm{t}}^{\mathrm{p}} / \varepsilon_{\mathrm{c}}^{\mathrm{p}}$, Plastic strain $(\mathrm{t}=$ tension and $\mathrm{c}=$ compression $)$

$\theta$, Temperature

$v$, Poisson's ratio

$\sigma_{\mathrm{t}} / \sigma_{\mathrm{c}}$, Stress $_{(\mathrm{t}=\text { tension and } \mathrm{c}=\text { compression })}$

$\mathrm{f}_{\mathrm{b} 0} / \mathrm{f}_{\mathrm{c} 0}$, ratio of initial equibiaxial to uniaxial compressive yield Stress

$\mathrm{K}$, is the ratio of Stress invariant on tensile meridian to compressive meridian.

DIF, Dynamic Increase Factor

R'/R'/R',, Radial distance

\section{REFERENCES}

[1] ABAQUS 6.14.(2014). User Documentation, Dessault Systems.

[2] Adam, J.M., Brencich, A., Hughes, T.G., and Jefferson, T. (2010). Micro modelling of eccentrically loaded brickwork: study of masonry wallettes. EngStruct 2010;32(5):1244-51.

[3] Agrawal, P., and Srikhande, M. (2006).Earthquake Resistant Design of Structures. PHI learning private limited, Delhi.

[4] Akhaveissy, A.H. and Desai C.S. (2011). Unreinforced Masonry Walls: Non Linear Finite Element Analysis with Unified Constitutive Model. Archives of computational methods in engineering. Springer, 2011, 18, 485-502.

[5] Alsayed, S.H., Elsanadedy, H.M., Al-Zaheri, Z.M., Salloum, Y.A., and Abbas, H. (2016).Blast response of GFRP-strengthened infill masonry walls. Construction and Building Materials, 115, 438-451.

[6] Daniell, A.J., and Dubey, R.N. (2014).Finite Element Simulation of Brick Masonry Building under Shock Loading.Tenth U.S. National Conference on Earthquake Engineering, Frontiers of Earthquake Engineering July 21-25, 2014, Anchorage, Alaska.

[7] Faghihmaleki, H., Nejatil, F., Mirzagoltabar-Roshan, A., and Batebi-Motlagh, Y. (2017). An Evaluation of Multi-Hazard Risk Subjected to Blast and Earthquake Loads in RC Moment frame with Shear Wall. Journal of Engineering Science And Technology Vol. 12, No. 3 (2017) 
636 - 647. School Of Engineering, Taylor's University.

[8] Gabor, A., Ferrier, E., Jacquelin, E., and Hamelin, P. (2006). Analysis and modelling of the in-plane shear behaviour of hollow brick masonry panels. Constr Build Mater 2006;20:308-21.

[9] IS: 4991-1968 (Reaffirmed 2018). Indian Standard Code of Criteria for Blast Resistant Design of Structures for Explosions above Ground.Bureau of Indian Standards, New Delhi, India.

[10] Janaraj, T., and Dhanasekar, M. (2014). Finite element analysis of the in-plane shear behaviour of masonry panels confined with reinforced grouted cores. Constr Build Mater 2014;65:495-506.

[11] Jankowiak, T., and Lodygowski, T. (2005).Identification of Parameters of Concrete Damage Plasticity Constitutive Model.Foundation of Civil and Environmental Engineering 2005; 6: 53-69.

[12] Kaushik, H.B., Rai, D.C., and Jain, S.K. (2007). Stress-strain characteristics of clay brick masonry under uniaxial compression. Journal of Structural Engineering, ASCE2007; 19: 728-739.

[13] Khan, S., Saha, S.K., Matsagar, V.A., and Hoffmeister, B. (2017).Fragility of Steel Frame Buildings under Blast Load.Journal of Performance of Constructed Facilities, C ASCE, ISSN 0887-3828. DOI:10.1061/(ASCE)CF.1943-5 509.0001016

[14] Kowalewskia, L., and Gajewskia, M. (2015). Determination of failure modes in brick walls using cohesive elements approach. Procedia Eng 2015;111:454-61.

[15] Lee, J., and Fenves, G. L. (1998).Plastic-Damage Model for Cyclic Loading of Concrete Structures," Journal of Engineering Mechanics, vol. 124, no. 8, pp. 892-900, 1998.

[16] Li Z., Chen L., Fang Q., Hao H., Zhang Y., Xiang H., Chen W., Xiang H.. andBao Q. (2017). Study Of Autoclaved Aerated Concrete Masonry Walls Under Vented Gas Explosions. Engineering Structures. Volume-141 (2017), pg. 444-460.

[17] Lourenco, P.B. (1996). Computational strategies for masonry structures. $\mathrm{PhD}$ Thesis. Delft University of Technology, Delft, The Netherlands; 1996.

[18] Lourenco, PB. (1998). Experimental and numerical issues in the modelling of the mechanical behaviour of masonry. In: Roca P, editor. Structural Analysis of Historical Constructions II. Barcelona: CIMNE; 1998. p. 57-91.

[19] Lubliner, J., Oliver, J., Oller, S., and Onate, E. (1989).A Plastic-Damage Model for Concrete.International Journal of Solids and Structures, vol. 25, pp. 299-329, 1989.

[20] Mohamad, A.A.E., and Chen, Z. (2016).Experimental and Numerical Analysis of the Compressive and Shear Behavior for a New Type of Self-Insulating Concrete Masonry System. Appl. Sci. 2016, 6, 245; doi:10.3390/app6090245.

[21] Najafgholipour, M.A., Dehghan, S.M., Dooshabi, A., and Niroomandi A. (2017).Finite Element Analysis of Reinforced Concrete Beam-Column Connections with Governing Joint Shear Failure Mode. Latin American
Journal of Solids and Structures. DOI: 10.1590/1679-78253682.

[22] Nayal, R., and Rasheed, H.A. (2006). Tension stiffening model for concrete beams reinforced with steel and FRP bars. Journal of Materials in Civil Engineering, vol. 18, pp. 831-841,

2006.DOI:10.1061/(ASCE)0899-1561(2006)18:6(831)

[23] Pandey, A.K., and Bisht, R.S. (2014).Numerical Modelling of Infilled Clay Brick Masonry under Blast Loading. Advances in Structural Engineering Vol. 17 No. 42014.

[24] Pela, L., Cervera, M., and Roca, P. (2011).Continuum damage model for orthotropic materials: application to masonry.Comput Methods ApplMechEng 2011;200:91730 .

[25] Rots, J.G. (1997).Structural masonry: an experimental/numerical basis for practical design rules. Rotterdam: Balkema.

[26] Sevim, B., and Toy, AT. (2019). Blasting Response of a Two-Storey RC Building Under Different Charge Weight of TNT Explosives. Iranian Journal of Science and Technology,

Transactions of Civil Engineering https://doi.org/10.1007/s 40996-019-00256-0

[27] Shamim, S., Ahmad, S., and Khan, R.A. (2020). An Investigation on Response of Blast Load on Masonry Structure. Lecture Notes in Civil Engineering 58, https://doi.org/10.1007/978-981-15-2545-2_44.

[28] Sielicki, P.W., and Łodygowski, T. (2019).Masonry wall behaviour under explosive loading. Engineering Failure Analysis 104 (2019) 274-291.

[29] Stewart, M.G., and Netherton, M.D. (2014).Reliability-Based Design Load Factors for Explosive Blast Loading. Journal of Performance of Constructed Facilities, ASCE, ISSN 0887-3828.

[30] Stochino, F., Attoli, A., and Concu, G. (2020). Fragility Curves for RC Structure under Blast Load Considering the Influence of Seismic Demand. Appl. Sci. 2020, 10, 445; DOI: $10.3390 / \mathrm{app} 10020445$.

[31] Unified facilities criteria: UFC 3-340-02 (2008). Structures to resist the effects of accidental. Department of Defense, United States of America, 2008.

[32] Varma, R.K., Tomar, C.P.S., Parkash, S., and Sethi, V.S. (1996). Damage to brick masonry panel walls under high explosive detonations. ASME-Publications-PVP, 351, $207-$ 216.

[33] Verma, S., and Paul, B. (2017).To Investigate the Contribution of Steel Reinforcement in Corner Region of Masonry Wall for Improving Key Connection.DOI: 10.9790/1684-1403040114.

[34] Yasser, E.I., Mostafa, A.I., Marwa, N. (2017). Response of Reinforced Concrete Frame Structures under Blast Loading. Procedia Engineering Volume 171, 2017, Pages 890-898.

[35] Yu R., Chen L., Fang Q. AndHuan Y. (2017). An improved nonlinear analytical approach to generate fragility curves of reinforced concrete columns subjected to blast loads. 
